\title{
Enhancing Students' Writing Ability Using Corrective Feedback through Lesson Study In Nusantara PGRI Kediri University
}

\author{
Lina Mariana \\ English Education Department \\ University of Nusantara PGRI Kediri \\ Linamariana1009@yahoo.co.id
}

\begin{abstract}
Everyone knows that learning English as a second language needs huge efforts in mastering the language components known as the aspects of language skills, such as; Writing skill, they are: grammar, structure, mechanics, vocabulary, ideas and organizing it as well. The objectives of this research are 1) to know the process of teaching writing using corrective feedback through Lesson Study program and 2) to know the result of students writing ability taught by corrective feedback through Lesson Study. Lesson Study provides the lecturers or teachers to conduct a well-prepared (organized) lesson plan in their class. Any single activities in teaching the students will be evaluated well by the collaborative team. By conducting Plan, Do and See cycle in this research, there will be no useless times to spend by the lecturers and the students as well.. The lecturer needs to do corrective feedback as it is considered as one of the language assessment that can be done usefully by the lecturers since the students need to know whether what they did is right or wrong. Moreover the students need to know what kinds of mistakes they made to make their next product is better.
\end{abstract}

Keywords—writing; corrective feedback; Lesson Study

\section{INTRODUCTION}

Writing is important because not only reinforces grammatical structures, idioms and vocabulary but alsothe students have a chance to be adventurous with the language and finally the students are very involved with the new language. In this part, the students have a unique way to reinforce learning by combining constant use of eye, hand, and brain. Teaching writing enables teachers to be braver in giving students the appropriate way to have them write what is on their minds and working on any information comes to them. Learning writing can be used as a means to pursue learners' dreams whether academically or non-academically.

However, there are some difficulties related to writing. The psychological difficulty in which the writer has to decide what information the readers need. Furthermore, there is a linguistic difficulty in that language used in written language that is different from that used in speech and in addition, there is a cognitive difficulty in which the students have to organize their obliged to write and they do not know what to write more on their paper.
Preliminary research which include observation, test, questionaire, and interview showed that the difficulty faced the most for students in writing was on developing ideas in paragraph. This was indicated from some following problems: a) the students' difficulties on Grammatical structure, b) the students' difficulties in finding appropriate vocabularies upon sentences they made, and c) the students' difficulties in organizing their ideas into paragraphs.

From the conditions above, a lecturer should give some alternatives to students about how to write a good paragraph, whatever the paragraph is. So, their writing will be meaningful, well-organized, unity and also coherent. In relation to the use of giving corrective feedback activity, there have been some studies conducted at several schools, especially in junior high school and senior high school. The finding of the previous studies show that this activity is effective and helpful for the students and the teachers, but the emphasis of conducting this research is how I help the students in organizing their ideas, so that their writing result will be organized well, their sentences will be arranged in a right unity and coherent.

\section{LITERATURE REVIEW}

\section{A. Writing}

Writing, particularly academic writing is not easy. Reference [1] state that academic writing takes study and practice to develop this skill. For both native speaker and new learners of English, it is important to note that writing is a process not a "product". This means that a piece of writing, whether it is composition for the English class or lab report for our chemistry class is never complete, that is, it is always possible to review and revise, and review and revise again. Writing is the production of the written word that results in a text but the text must be read and comprehended in order for communication to take the place. To reach the result of well written text, the writer must be extremely careful with the writing components, such as its grammar, conjunction, punctuation, spelling, word choices, coherence and unity. The way how to organize the ideas, will influence the result of our writing whether it is communicable, understandable or not. 
Writing serves as an important tool to measure learner's competence in the form of writing tests in major examinations such as the TOEFL and IELTS writing sub-test. Besides, writing is essential in academic terms as it appears in the form of conference presentations, journals, and book publication where new thoughts, ideas, and concepts can be welldelivered. Writing is important due to some reasons, namely: 1) Communication. In the term of communication, she explains that writing is essential to express feelings through letters, daily journal, memo, and notes. Also, it is for expressing ideas, including plans, recommendations, values, and commitments, however the various purposes. 2) Critical thinking and problem solving. Writing helps people to think critically dealing with some information around them. Writing becomes a way to define them as it is used to express their thoughts and the way they react to certain problems. 3) Selfactualization. As a means of self-actualization, writing is necessary to discover who we really are and how to make ourselves well-developed. Further, it can improve other language skills, such as reading, listening, and speaking. 4) Control of personal environment. This means that people are able to build communication through writing in Englishspeaking environment. Here, they can manage how to apply their English in their daily life.

\section{B. Corrective Feedback}

Corrective feedback is information about reactions to a product, a person's performance of a task, used as a basis for improvement. Corrective feedback is a type of feedback with the purpose to correct any errors committed by students. Corrective feedback can be both on form and content of writing. Corrective feedback on form includes grammar and mechanics, i.e. spelling, punctuation, vocabulary. Corrective feedback on content focuses on organization, ideas and amount of detail. In conclusion, corrective feedback is information that is given by the teacher to students' writing product with the aim to develop learners' writing. By giving corrective feedback, the teacher knows student's performance with the ideal and to diagnose student's strengths and weaknesses.

\section{Types of Corrective Feedback}

Feedback is divided into two types. They are oral and written feedback. Oral feedback refers to the provision of feedback on errors and weaknesses in content, organization, and language through face-to-face conferencing that can be done by giving comments in the form of questions, imperatives, praise, and suggestions. Oral feedback is one of many communication forms where students receive feedback from their teacher who either corrects them implicitly or explicitly or asks them to clarify what they say or write. It means that it is way of responding to students' writings in which a two party conversation between students and lecturer takes place in order to discuss and deal with written products.

Written feedback can be categorized into direct and indirect feedback. Direct feedback refers to overt correction of student errors, that is, teachers locating and correcting errors for students' writing. The teachers normally put the symbols, codes, or comments right above or next to the errors which is underlined or circled. The principle in the direct feedback is that the teacher shows the correction of the errors. Indirect feedback refers to teachers indicating errors without correcting them for students. It means that teachers will locate errors directly by underlining or circling the errors to indicate an error on a certain line. The principle in the indirect feedback is that the teachers do not show the correction of the errors.

\section{Aspects of Corrective Feedback}

According to Jacobs et al (1981:90), there are several aspects in giving corrective feedback.

\section{1) Content}

Content refers to the substance of writing. Content consists of main idea, topic sentence, supporting sentence, supporting detail, and concluding sentence. Main idea is identified by seeing the topic sentence. The role of main idea is to guide the writer to focus on their writing. Supporting sentence is a sentence which explains topic sentence, while supporting detail is a sentence which explains supporting sentence. At last, concluding sentence is a sentence which gives conclusion based on the whole of paragraph.

\section{2) Organization}

Organization refers to the logical organization of the content (coherence). It is related to the ideas that hold together so that ideas run smoothly within paragraph.

a) Grammar

Grammar refers to the use of the correct grammatical forms and syntactical pattern. It is identified form the construction of well-formed sentence.

\section{b) Vocabulary}

Vocabulary refers to the selection or words those are suitable with the content. It can be identified by seeing the words choice or diction in order to convey ideas to the reader.

c) Mechanics

Mechanic refers to use of graphic conventional of the language. It is identified by seeing the usage of spelling, punctuation and capitalization within the paragraph.

Thus, to make the text or paragraph meaningful, the students or writer must give attention to those aspects or components of writing, there are content, organization, grammar, vocabulary, and mechanic that will be packaged well by corrective feedback delivered by the lecturers.

\section{E. The Process of Corrective Feedback}

On Experience Practive book (2015:6), there are some requirements that must be mastered by the lecturer in presenting a clear explanation. One of them is the lecturer must be able to give a feedback for student's writing product. The lecturer can give feedback in oral and written. According to Brookhart in How to Give Effective Feedback to Your 
Students Book (2013), oral feedback and written feedback have each process on giving corrective feedback. Process on giving oral feedback is firstly, the lecturer gives one topic and she starts to discuss the topic and model of composition. In this sense, she needs to make sure that the students understand the topic being discussed by asking them some related about the topic. Second, the lecturer allows the students to use their ideas, information, and notes to plan their compositions. The students asked to write freely about the topic on the paper. The focus in this phase is organizing ideas. Third, when the students are planning and organizing his ideas, the lecturer can comment on the unity and coherence of ideas. In this regard, the lecturer should give oral feedback many times between drafts, not just one time when students submit their final draft. After, the students finish the task. The lecturer asks some students to show or write their final draft in front of class. Before, the lecturer assesses and gives oral feedback on their final draft. She gives other students a chance to find the difficulties of the task then ask for clarification. After that, the lecturer assesses and gives some feedback to their final draft.

Next, process on giving written feedback is when the students have already written a clear final draft. They submit their writing to the lecturer. The lecturer has to assess and gives some feedback on their final draft.

\section{F. Lesson Study}

Lesson study procedure in Stigler \& Hiebert in Baba (2007: 2) can be seen in Fig. 1.

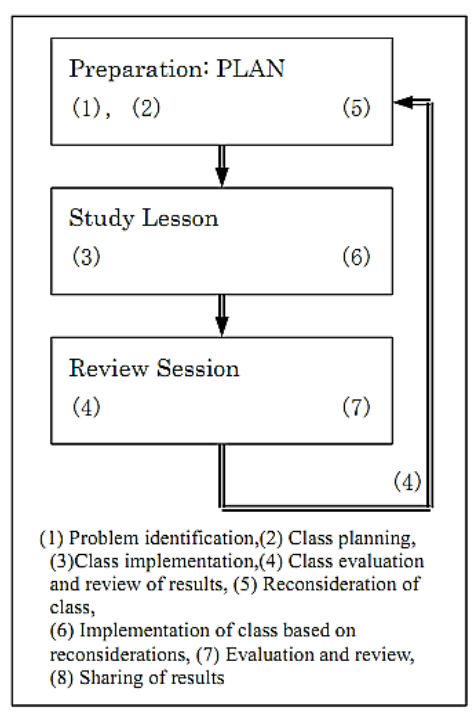

Fig. 1. Lesson Study procedure

\section{METHOD}

The method used by the teachers in writing classroom is Lesson Study. It was done in 3 cycles. Each cycle consists of Plan-Do-See as it is stated by Fernandez \&Yoshida. Lesson Study is held in a set of activities namely Plan-Do-See. In Plan stage, the team worked together to prepare the students need such as, handout, worksheet, lesson plan, media, arranging good activities and all the details before teaching. All students' need are based on preliminary research done by the writing lecturer as a model. In do stage, the model applied what they had managed before with her team based on the preparations that they have managed before while the observers would observe and evaluate the students' attitude and what the lecturer did during teaching learning process. The reflection done is to find out the strength and the weakness of conducting lesson study in writing class. All the weakness would be revised for the next meeting. We all realize that working in a professional group, the best things would be resulted. All observers may have their critical thinking about what the lecturer model has to do in her class based on the students' need and students' problem in writing classroom. The aspects of writing that must be mastered by the students will also be helped by the lecturers as what the observers suggested on the learning community when see stage is held. Meeting together for exploring the suggestion, solving the problems, revealing the fact when teaching learning process is conducted will be the point of what the team does in learning community.

\section{RESULT}

The process of teaching and writing usethe corrective feedback through lesson study program is done by the researcher when she delivered the material in front of the class then giving correction to the students work orally and written together. It means that corrective feedback is delivered by the lecturer to the students after the students submitting their work. It is corrected orally as the lecturer gave some comments to the students work when it is presented in front of the class through power point presentation. While written corrective feedback is given to the students' worksheet or page by giving some notes.

The students ability in writing can be improved significantly after they are taught using corrective feedback. The students' product here is in form of short stories. After they are involved in the content of story, the students' enthusiasim extreemely increased. Knowing the story well by analysing it through the basic intrinsic elements encourage them to be enthusiastic to retell the content of the story by their own style. The students' interest can be about the flow of the story or plot, it can also be about the conflicts found in the story.

Furthermore, knowing the characteristics may encourage students to be curious in the story ending. Knowing that there are other people feel the same in facing the life's problem, it will spur their motivation to read, to re-write the story using their own style since they are influenced by their own heart feeling the story, the ways how the main character faces her/his life's problems, the ways how he/she solves the problems well. What the students feel in heart will be the special motivation to develop and expand their ideas without deciding how many pages they have to write.

The most important thing for the student who is in his best motivation is paying close attention to what he feels not what he thinks. What he will write is only about what he feels upon the story. After they get involved with the story, the students' 
problems in writing may be solved well, they are: it will be quite fun for them to start writing after reading a nice short story since they are encouraged to retell the story again, consisting how the story begins, how the climax happen, what resolution the story has, what kind of characteristics that the characters explore, and so forth. The students' curiousity in being involved through the story will motivate them to write more and more. Finally, the students are expected not getting stuck in the middle of writing until they can represent the moral judgment.

The result of the students' writing ability after they are taught using corrective feedback through lesson study program can be examined carefully through their score based on same aspects as it was evluated by the lecturer to know whether the students' work improved well or not. Students are warmly invited to enjoy their time by reading short story. Knowing precisely the conflicts happen between the characters may increase the students feeling and thought to be involved in that story since the students have the similar conflict in their life. The ways how the character solve the problem may encourage them to be more wise in taking final decision upon their life's problem. Even though the students do not have the similar conflict, at least they will learn how to be wise in deciding the way out of each problem in life.

As everybody knows that imaginative literature aims to entertain readers by moving the readers' feeling and tought. After reading the story, it is expected that they will understand the story well by being able to get feeling and thought in taking the conflicts, getting the resolution of the problem, understanding the main character's feeling in facing the most difficult problem in climax. The writer will focus on taking the readers' attention in feeling the difficult situation in main character's life, in feeling hard of taking resolution and so forth. If there are some special feelings on the readers heart and thought, it means that the writer is sucessful in taking the readers' attention. When all students are greatly busy in paying attention to the content of story, the class will be quiet for a moment.

Then after a few minutes passed, there will be some questions related to basic intrinsic elements of short story to the students. And all their answers must be done by writing them correctly based on the aspects of writing. If getting ideas become the most important problem in writing, then by their special interest in the content of the story, it may lead them to write better in ideas because they are motivated in expressing what they feel and what they think about the content of the story.

Different material delivered to the students may also become one of the ways in decreasing the boring situation in writing classroom. Depending on the materials that will be delivered to the students are all about non fiction material, it is a time for the lecturers to change the material to be written. Some say that letting the students free in expressing their ideas will lead them to be more creative in writing since the ideas are also free. Free here means that the material is not far from their life. Happiness, sadness, proudness, being honoured are kinds of human feelings in facing life that can be appeared anytime that they have to be the wise decision maker. The students' interest upon the story will encourage them to express freely and fun. All about what their heart say will be the material in writing. Finally there is no reason of saying that they get lost the ideas in the middle of writing. The students must realize also that their heart and thought are full of feelings upon the content of the story. They will be more creative if they are let to decide what kind of ending of the story that they want to give, whether sad or happy.

Not only the students' brain will work but also their heart or emotion as well. Doing a work involving our heart is something challenging, something fun. Hopefully this situation or assumption will be proved easily by the students who learn about how to write dealt with the material that they have to. It will be the students' media in expressing what their heart says. They can explore what in her heart upon the story using a group or a series of coherent sentences. We can not limit how many pages their point of view based on the story. They are free to write. They love the material then we can see how short story may develop the students' ideas in writing. The students enthusiasim in presenting the story using their own understanding and style will be the major source of producing their creative writing.

\section{CONCLUSION}

It can be concluded that knowing the students' problem is important for lecturers to help them in learning language. Since it is a learning process, some difficulties may appear during the learning process. By knowing the students' problem, students will find the best way how to be out of their problem. After getting the students' problem in writing is about the ideas, the lecturer may be able to find out the best way or the best manner to help them so that the teaching learning process will run smoothly.

If the students get bored in learning language, it will also be the lecturers' problem that must be solved sooner since it will influence their score at the end of teaching learning process. The students' success will be the lecturers' success too. It means that knowing the students factor in getting bored must be the lecturers' problem also, then giving questionaires is one of the ways to find out the answer. And after knowing that getting familiar or popular topic will also be the students' way out of problem, then changing the material will be the alternative of getting out of the problem. After the students are used to be given non fiction material to be written, introducing them to the fiction material needs to be applied.

The students are interested in fiction story such as short story that will be finished at one sitting, since they can feel that they are involved in the story, it seems that they are one the characters in the story. Furthermore, when the students feel that the content of the story is similar to what happen in their life, it will also be their special motivation to write better than the author of the story. What the students feel and think will quite influence to what they will write. If the author of the story is able to take the readers' attention, in this case the students, it will be easy for students to write better because not only the way of thinking will be involved but also how they 
feel will encourage them to write more creative than before. Giving corrective feedback is one of the activities to improve the students' product and to avoid boredom situation.

The weakness of this study is giving the students short stories even though in different plot, will cause boredom situation in each meeting. Finally the lecturer must be more creative and selective in choosing the short story and do different or fun activities upon the short story itself. The lecturers must think hard how manage the activities dealing with the short stories as the material given to the students in writing. Sometimes giving some questions to the students dealing with their level will keep this way is permanently able to be given to the students without worrying the boredom situation.

Recognizing our students well will be the most important thing in our effort to improve their ability in language skills. Finally, the students' attitude and their behaviour in classroom during teaching learning process must be the lecturer's attention also to know better whether they enjoy the classroom or not, whether they understand the material or not, whether they like the way how the lecturer teaches them or not, and so forth. Thus paying close attention to the students' attitude during teaching learning process will help the lecturer to find out the best media, strategy, approach or method to be applied in teaching the students.

At last, all the ways we can go through for helping students' effort at improving their ability in language skill must be the lecturers' duty and responsibility, as in writing skill. Corrective feedback is extreemely needed by the students in writing subject since they all want to improve their work especialy in getting good score by producing the best product.

\section{References}

[1] Oshima, Alice and A. Hogue, Writing Academic English (Paperback). New York: Addison Wesley Longman, 1983. 